\title{
Trophic dynamics in a relatively pristine subtropical fringing mangrove community
}

\author{
E. Raymond Heithaus ${ }^{1}$, Patricia A. Heithaus ${ }^{1}$, Michael R. Heithaus ${ }^{2, *}$, \\ Derek Burkholder ${ }^{2}$, Craig A. Layman ${ }^{2}$
}

\author{
${ }^{1}$ Biology Department, Kenyon College, Gambier, Ohio 43022, USA \\ ${ }^{2}$ Program in Marine Sciences, Florida International University, 3000 NE 151st St., North Miami, Florida 33181, USA
}

\begin{abstract}
Mangroves provide important habitats for many species throughout the tropics and subtropics. But the direct contribution of mangrove productivity to associated food webs through trophic interactions varies depending on site-specific context. We used stable isotopes to examine trophic structure among major habitat types associated with 2 fringing mangrove areas in Shark Bay, Western Australia, a nearly pristine ecosystem. The only mangrove species, Avicennia marina, had a distinctive $\delta^{13} \mathrm{C}$ isotopic value, which allowed direct testing of the hypothesis that consumers relied on mangrove-derived production. We found little evidence to support this hypothesis in isotope values of invertebrates or fish from 4 different feeding guilds. Within the species of fish we were able to sample, variation in $\delta^{13} \mathrm{C}$ and $\delta^{15} \mathrm{~N}$ stable isotope values occurred over spatial scales of hundreds of meters. Some of this variation is consistent with the spatial mosaics of seagrass, sand flat and mangrove habitats available to fish. In a nearly pristine system, fish captured in mangrove systems show fine scale variability in stable isotope values, but we found no indication that mangrove productivity directly supported local fish populations through the trophic web.
\end{abstract}

KEY WORDS: Energy flow $\cdot$ Fish $\cdot$ Food web $\cdot$ Seagrass $\cdot$ Stable isotope analysis $\cdot$ Australia

Resale or republication not permitted without written consent of the publisher

\section{INTRODUCTION}

Habitats at terrestrial-ocean boundaries can influence nearby marine ecosystems more than might be predicted based on their size alone. Mangroves, in particular, are thought to affect both primary and secondary productivity well beyond intertidal zones (Duffy 2006, Nagelkerken et al. 2008, Nagelkerken 2009). Links between mangroves and surrounding marine habitats are driven by active movement of animals and by the exchange of nutrients through currents and tides. Mangrove habitats, however, can vary substantially in their structure and function (Ewel et al. 1998). The importance of mangroves to populations of fish is highly variable among systems (Faunce \& Serafy, 2006), which may be due to spatial structure (landscape characteristics), temporal dynamics (hydrodynamics) or species composition (Lugendo et al. 2007, Faunce \& Layman 2009).
Mangrove systems are often classified into 3 major categories: 'fringing mangroves', which are typically narrow in extent and occur along embayments, lagoons or sheltered ocean coasts; 'riverine mangroves', which lie along estuarine river banks and are of variable salinity; and 'basin mangroves', which are found behind fringe and riverine mangroves and have variable degrees of tidal flushing (Ewel et al. 1998). In riverine mangroves, mangrove trees with prop roots or pneumatophores add physical structure in the water column that increases protective cover and surface area for epibiota, thereby increasing the diversity and abundance of invertebrates and juvenile fish. Further, riverine and basin mangrove sediments often are rich in organic carbon and favor burrowing benthic invertebrates and infauna (Nagelkerken et al. 2008). In contrast, fringing mangroves often have few of the characteristics that make riverine mangroves so important in supporting high biodiversity and productive fisheries (Ewel et al. 1998). 
Feeding activities of fish is one process linking mangroves to other local habitats. Fish in mangrove habitats can vary their feeding behavior in response to local variation in prey abundance and predation risk (Laegdsgaard \& Johnson 2001, Sanchez-Jerez et al. 2002, Unsworth et al. 2007), which may modify crosshabitat linkages. Many species of fish found in fringing mangroves are considered 'opportunistic,' shifting feeding locations and prey items in response to local conditions (Hammerschlag-Peyer \& Layman 2010). Such shifts may be particularly pronounced in mangrove systems with low prey availability and, thus, could lead to greater connectivity to non-mangrove food webs.

In this study, we explored food web structure and feeding relationships in fringing mangrove habitats of the relatively pristine ecosystem of Shark Bay, Western Australia. We used patterns of stable isotope variation of invertebrates and fish to infer to what degree mangroves were directly supporting secondary production. We were especially interested in the extent to which fishes with different feeding strategies depend on mangrove-derived primary productivity. We also examined potential sources of variation in fish isotope values with a particular focus on (1) the influence of body size within species and (2) a landscape level variable, i.e. extent (i.e. total size) of mangrove habitats. Food web models in little-impacted ecosystems, like Shark Bay, are very rare (but see Abrantes \& Sheaves 2009); thus, this study provides valuable benchmarks for comparison of trophic dynamics with hydrologically comparable systems more impacted by human activity.

\section{MATERIALS AND METHODS}

Study location. Shark Bay is a $13000 \mathrm{~km}^{2}$ subtropical embayment with an average depth of $9 \mathrm{~m}$, located on the central coast of Western Australia. The bay is subdivided by peninsulas and barrier islands into the Eastern and Western Gulfs (see Heithaus 2004). Shark Bay has a pronounced salinity gradient increasing to the south and east and reaching up to $70 \%$ in Hamelin Pool in the extreme SE corner of the bay (UNEP, World Conservation Monitoring Centre 2008). Designated as a Marine Park and World Heritage Area in 1991, Shark Bay is subject to very low fishing pressure and is one of the world's most pristine remaining seagrass ecosystems.

Habitats of Shark Bay create an interconnected mosaic (Sheaves 2009). This mosaic includes extensive shallow seagrass beds, sandy unvegetated areas, deeper-water mixes of sand and sparse seagrass, fringing mangroves, and intertidal sand flats. The dominant seagrasses Amphibolus antarctica and Posidonia aus- tralis, and a mix of less common tropical seagrass species, cover $\sim 4000 \mathrm{~km}^{2}$ of Shark Bay (Walker, 1990). Mangroves occur along $\sim 30 \%$ of coastal fringes of the study area with Avicennia marina (gray mangrove) being the single species. Most of this fringe is narrow, consisting of a thin line of trees, but larger, protected bays are scattered through the east bay. These larger bays tend to have compact, hard, gypsum-dominated sediments with low organic content and very little accumulated detritus. Even the bays are marinedominated, with freshwater input occurring infrequently (e.g. during cyclones).

We selected 2 mangrove systems (Dubaut Creek and Guichenault Point) along the eastern coast of Peron Peninsula and sampled organisms from 3 subsites at each location (Fig. 1). These were selected because they had the largest patches of accessible mangrove. Guichenault Point creates Herald Bight within which the protected southwest and west shores are lined with tidal creeks, mangroves and mud flats (Guichenault Interior; GI). The boundary between the tidal creek and bay was designated Guichenault Mouth (GM). The east side of Guichenault Point is more exposed to the Eastern Gulf, except for a small lagoon (Guichenault Lagoon; GL) that is lined with mangroves and where seagrass detritus creates a permanent flocculent layer over the sandy sediments. Salinity in Herald Bight tends to vary little $40 \%$ o (Travers \& Potter 2002, White \& Potter 2004).

Dubaut Creek, $35 \mathrm{~km}$ south south-east of Guichenault, is a tidal creek connected to a birrida (a hypersaline land feature with saltbush, Salicornia, and soils dominated by gypsum clay). We sampled in the tidal channel and intertidal flats up to $1200 \mathrm{~m}$ from the creek mouth (Dubaut Interior, DI) and at the mouth of the tidal creek (Dubaut Mouth; DM). Southeast of the entrance to Dubaut Creek is a smaller creek with a low density of mangroves (Dubaut Point; DP) and a short $(150 \mathrm{~m})$ tidal creek that drains a largely-unvegetated area of gypsum clay. Salinity in Dubaut Creek and near Dubaut Point ranged from 42 to $50 \%$ in June 2008. We also sampled at sites well removed from potential mangrove influence, including seagrass habitats (SG) and sandy intertidal (MM) near Monkey Mia, $21 \mathrm{~km}$ south of Guichenault and $8 \mathrm{~km}$ north of Dubaut.

We used geographic systems analysis software (ArcGIS) to calculate areas of aquatic habitat types available to fish near the entrances to each of the 4 mangrove subsites. Habitat polygons were classified as fringing mangrove, channel, sand, seagrass, seagrass-sand mix, or detritus-sand mix, using visual interpretation of a $1 \mathrm{~m}$ resolution orthophotograph taken in 2006. Habitat patches were identified within $1 \mathrm{~km}$ of the mouth of each subsite, using the shortest path available to fish. The distance of $1 \mathrm{~km}$ was 
Fig. 1. Eastern Gulf of Shark Bay, Australia $\left(25^{\circ} 45^{\prime} \mathrm{S}, 113^{\circ} 44^{\prime} \mathrm{E}\right)$. Study sites. Insets: detailed locations of Guichenault and Dubaut study sites

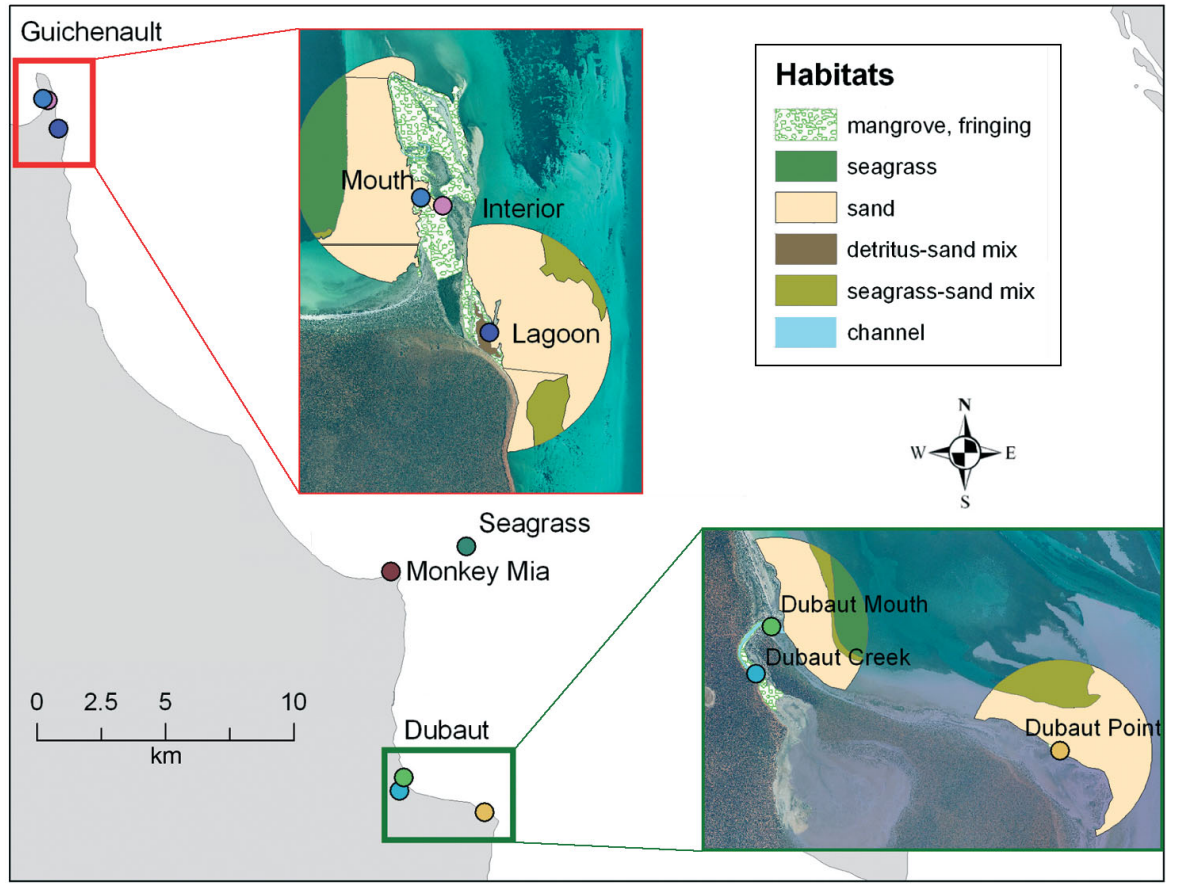

selected to encompass habitats that would be reasonably encountered by fish moving with tides between mangrove and deeper habitats. Daily movements with tides are documented in Caribbean and Australian systems, even though precise pathways are difficult to quantify (Meynecke et al. 2008, Luo et al. 2009, Mendoza-Carranza et al. 2010, Sakabe \& Lyle 2010) The 'shortest path' was a straight line except when land projected into the area. Areas for habitat patches of each type were then summed.

Sample collections and processing. Collections were made between 27 May and 14 July 2008. During this time the water temperature ranged from 17 to $24^{\circ} \mathrm{C}$. Fish from mangrove habitats were captured using traps, seines, and dip nets. We sampled from seagrass beds (SG) using fish traps and dip nets (see Heithaus 2004). Four species of fish were collected over sand using a dip net at the intertidal edge at MM. The sampling procedures were designed to obtain individuals from the most common species and was not intended to be a full survey or population estimate of the fish communities. Fish species were assigned to feeding guilds based on examination of stomach contents (authors' unpubl. data), a review of literature about fish in western Australia, and information from FishBase (Froese \& Pauly 2009). Identifications were assisted by Hoese et al. (2007).

Captured fish were placed on ice and frozen until processing. Total length was measured and, for individuals $>4 \mathrm{~cm}$, the dorsal and lateral muscle was removed, rinsed in distilled water, dried for 24 to $48 \mathrm{~h}$ at $60^{\circ} \mathrm{C}$ and then ground to a fine powder using a mortar and pestle. Smaller fish were rinsed, dried and ground whole. Samples were shipped to the United States in microfuge tubes and stored in a $-20^{\circ} \mathrm{C}$ freezer. Samples were redried at $60^{\circ} \mathrm{C}$ prior to weighing for isotope analysis.

Invertebrates were collected at each site and frozen until processed. We especially focused on collecting suspension-feeding bivalves and grazing gastropods to represent the invertebrate basal consumers in the mangrove food webs, as recommended by Post (2002), Layman (2007) and Mallela \& Harrod (2008). Bivalves were collected by manually sifting the sediments in a 2 $\mathrm{m}$ square area at Guichenault Interior and the edge of the channel draining Dubaut Creek. Small shrimp and crabs were collected by disturbing the sediments and sweeping vegetation with a large dip net. For large crabs, a single claw was removed. During processing, mollusks were manually separated from their shells and, when present, opercula were removed. Small crustaceans were dried whole and combined into samples of 10 to 25 organisms. Muscle was isolated from a single claw of large crabs. Tissue was rinsed in distilled water, dried and processed as described for fish.

For primary producers, Avicennia marina leaves were sampled directly from at least 5 trees per site. Samples were cut into small pieces to facilitate drying prior to grinding to a fine powder. We collected epibiota growing on pneumatophores of $A$. marina by cutting immersed pneumatophores, and then removing attached organisms by scraping with a razor blade. 
Seagrass and algal samples were collected as part of a larger study (D. Burkholder unpubl.). Epiphytes were removed with a razor blade from samples of all larger plants prior to drying and grinding. Seagrass and epiphytes were rinsed in distilled water prior to processing. Scraped samples were placed in aluminum trays and dried in a heated desiccator for at least $72 \mathrm{~h}$. Tissue was ground with mortar and pestle to a fine powder, stored in sealed vials and frozen after shipping to Florida International University (FIU) for processing of samples for stable isotope analysis.

Samples were processed at FIU following Post et al. (2007) for the determination of $\delta^{13} \mathrm{C}$ and $\delta^{15} \mathrm{~N}$. Some crustacean and algal samples required acidification to remove inorganic carbon. To acidify tissue, sample powder was placed in a glass watch glass and then into chamber containing $\mathrm{HCl}$ vapor. These samples were then dried $24 \mathrm{~h}$ at $60^{\circ} \mathrm{C}$ before weighing. A separate portion of unacidified sample was retained for $\delta^{15} \mathrm{~N}$ determination. For all samples $1 \pm 0.05 \mathrm{mg}$ of dried powder was placed in tin capsules and sent to the Yale Earth System Center for Stable Isotopic Studies (ISCSIS) for isotopic analysis. Large amounts of lipid can shift $\delta^{13} \mathrm{C}$ independent of diet, so numerical corrections of $\delta^{13} \mathrm{C}$ were calculated when the ratio of carbon to nitrogen, C:N > 3.32 as suggested by Post et al. (2007). The correction was used for at least 1 individual in $10 \%$ of taxa (Appendix 2) with an average correction of $-0.34 \%$.

Stable isotope values are reported using $\delta$ notation:

$$
\delta^{13} \mathrm{C} \text { or } \delta^{15} \mathrm{~N}=1000\left[\left(\mathrm{R}_{\text {sample }} \times \mathrm{R}_{\text {standard }}{ }^{-1}\right)-1\right]
$$

where $\mathrm{R}={ }^{13} \mathrm{C}:{ }^{12} \mathrm{C}$ or ${ }^{15} \mathrm{~N}:{ }^{14} \mathrm{~N}$.

The global standard for measuring $\delta^{13} \mathrm{C}$ is PeeDee belemnite and atmospheric $\mathrm{N}$ is used for $\delta^{15} \mathrm{~N}$. Our tissue standard was trout muscle, and at least 10 trout samples were interspersed through each run of 46 wells $\left(\delta^{13} \mathrm{C}_{\text {trout }}=-28.70 \%\right.$, SD $=0.106 \%$ o, $50.0 \% \mathrm{C}$; $\delta^{15} \mathrm{~N}_{\text {trout }}=15.79 \%$ o, SD $=0.081 \%, 13.1 \% \mathrm{~N}_{i}$ sample size $=42$ ).

Data analysis. Descriptive statistics, ANOVA and ANCOVA were run in Minitab. Data were evaluated for normality and homogeneity of variances. Variances of stable isotopes were homogeneous except for Pelates octolineatus for $\delta^{13} \mathrm{C}$ and Gerres subfasciatus for both isotopes. After $\log _{10}$ transformations of length, the assumptions of ANCOVA were met by data distributions for all species except $P$. sexlineatus.

Stable isotopic values often vary with body size (Gu et al. 1996, Shannon et al. 2001, Barnes et al. 2008), so log transformed length was included as a covariate in tests for site differences in $\delta^{13} \mathrm{C}$ and $\delta^{15} \mathrm{~N}$. The interaction between length and site was evaluated, but excluded from final models when $p>0.10$. Potential patterns in average $\delta^{13} \mathrm{C}-\delta^{15} \mathrm{~N}$ stable isotope values between sites were eval- uated using circular statistics with Oriana (Schmidt et al. 2007). Such analysis uses Rayleigh's Z statistic. In these analyses, replicates are average stable isotope values for species in common between pairs of sample sites. Circular statistics evaluate hypotheses about trends in shifts of position in a 2-dimensional space: $\delta^{13} \mathrm{C}-\delta^{15} \mathrm{~N}$ stable isotope biplots in our study.

\section{RESULTS}

The total amount of mangrove habitat varied among sites with GI >> DI > GL >> DP (Fig. 2). The areas of dense seagrass beds also varied among subsites, with GI again ranking highest.

Thirteen common species of fish were collected from 7 sites, with sample sizes varying from 1 to 45 per site (Appendix 1). The number of species encountered in the mangrove sites was consistent with relative amount of mangrove habitat for each site, with 10 species captured in GI, 6 in DI, 5 in GL and 3 from DP. Amniataba caudavittata and Rhabdosargus sarba were the most widespread species and each was captured from 5 sites; Pelates octolineatus was captured in 4 sites. The sample sizes do not reflect relative abundances of fish in the sampling areas because collections stopped when target numbers were obtained.

Fish taken from traps placed in seagrass beds tended to be larger than individuals captured in traps and nets in mangrove habitats (Appendix 1). On average, Pelates octolineatus and Amniataba caudavittata were larger than those from the largest mangrove sites by 135 and $36 \%$, respectively; Rhabdosargus sarba from seagrass were at least $39 \%$ larger than individuals from mangroves. Only Colurodontis paxmani were similar in size in seagrass and mangrove sites. Also

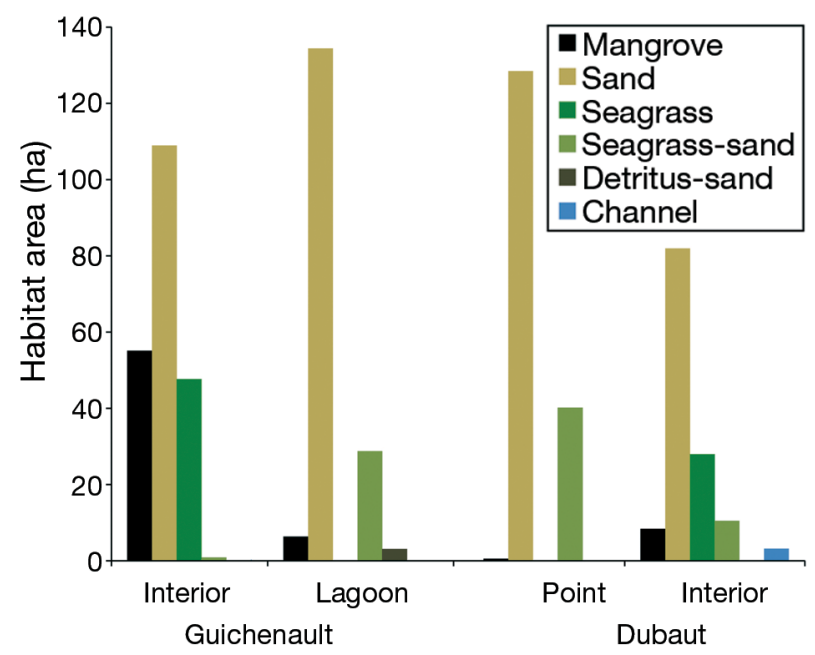

Fig. 2. Proportions of marine habitat types within $1 \mathrm{~km}$ of the mouth of the study sites 
varying in size among sites were the hardyheads Atherinomorus vaigiensis (larger in mangroves than in sandy subtidal) and Craterocephalus mugiloides (smaller in mangroves than in sandy subtidal).

\section{Primary producers from mangroves}

Avicennia marina leaves had similar $\delta^{13} \mathrm{C}$ values at Dubaut and Guichenault $(-22.9 \pm 2.6 \%$ at both; Fig. 3), similar to other studies of $A$. marina at other sites in Australia (e.g. Loneragan, et al. 1997, Werry \& Lee 2005). Epibiota (mostly algae) growing on the pneumatophores of $A$. marina were also relatively depleted in ${ }^{13} \mathrm{C}(-21.7 \%)$. Seagrass and seagrass epiphytes were considerably less depleted in ${ }^{13} \mathrm{C}$, with $\delta^{13} \mathrm{C}$ values ranging from -10.8 to $-7.1 \%$. We observed intermediate levels of $\delta^{13} \mathrm{C}$ values among algae collected from seagrass beds ( -16.3 to $-13.3 \%$, except for 1 sample of a calcareous red alga with a mean of $-21.3 \%$ o).

\section{Carbon sources for basal consumers}

It was not possible to directly measure the stable isotope signatures of all primary producers, particularly for benthic microalgae and pelagic phytoplankton. As such, we did not employ a model such as IsoSource (Phillips \& Gregg 2003). Instead, we used primary consumers (and invertebrates potentially eaten by fish) as an index of stable isotope values entering the base of the food webs among sites (e.g. Layman 2007). Appendix 2 gives sample sizes, sites and average stable isotope values by taxon.

If Avicennia marina or epibiota were important to these trophic pathways, tissue values should be rela- tively depleted in ${ }^{13} \mathrm{C}$. None of the invertebrate taxa displayed $\delta^{13} \mathrm{C}$ values that suggested significant reliance on mangrove primary productivity, and these patterns were consistent across mangrove sites and other sites (Fig. 4). The most ${ }^{13} \mathrm{C}$ depleted species, a tunicate, was collected from a seagrass bed more than 2 $\mathrm{km}$ from the nearest mangrove site. Only 6 invertebrate species were captured in mangrove and at least 1 other habitat, so rigorous statistical analysis was not possible; however, for all 6 of those species, the individuals from the mangrove habitat were less ${ }^{13} \mathrm{C}$ depleted than those collected from seagrass beds or sand flats. This is the opposite of the direction hypothesized if mangrove productivity was at the base of the trophic systems. $\delta^{13} \mathrm{C}$ values for invertebrates captured in mangroves (between -12 and $-14 \%$ ) were close to those of algae. The $\delta^{13} \mathrm{C}$ values of invertebrates from Monkey Mia were ${ }^{13} \mathrm{C}$-enriched, suggesting more reliance on seagrassbased trophic pathways. Organisms from the mangrove sites had isotope values generally similar to those from seagrass sites, except for bivalves, where seagrass-collected individuals were more depleted $\left(\delta^{13} \mathrm{C}\right.$ values of $-17 \%$ versus -12 to $-14.5 \%$ ), which again, is opposite from the direction predicted by the hypothesis of significant mangrove contribution to trophic webs.

\section{Carbon sources for fish}

Patterns in $\delta^{13} \mathrm{C}$ in fish that we were able to sample failed to support a prediction of increased reliance on Avicennia marina-based trophic pathways in the interior mangrove sites (DI and GI). Similar to invertebrate consumers, fish species from all feeding guilds (Elliott et al. 2007) were substantially less depleted in ${ }^{13} \mathrm{C}\left(\delta^{13} \mathrm{C}\right.$ averages ranged from -11 to $-17 \%$ ) than $A$. marina

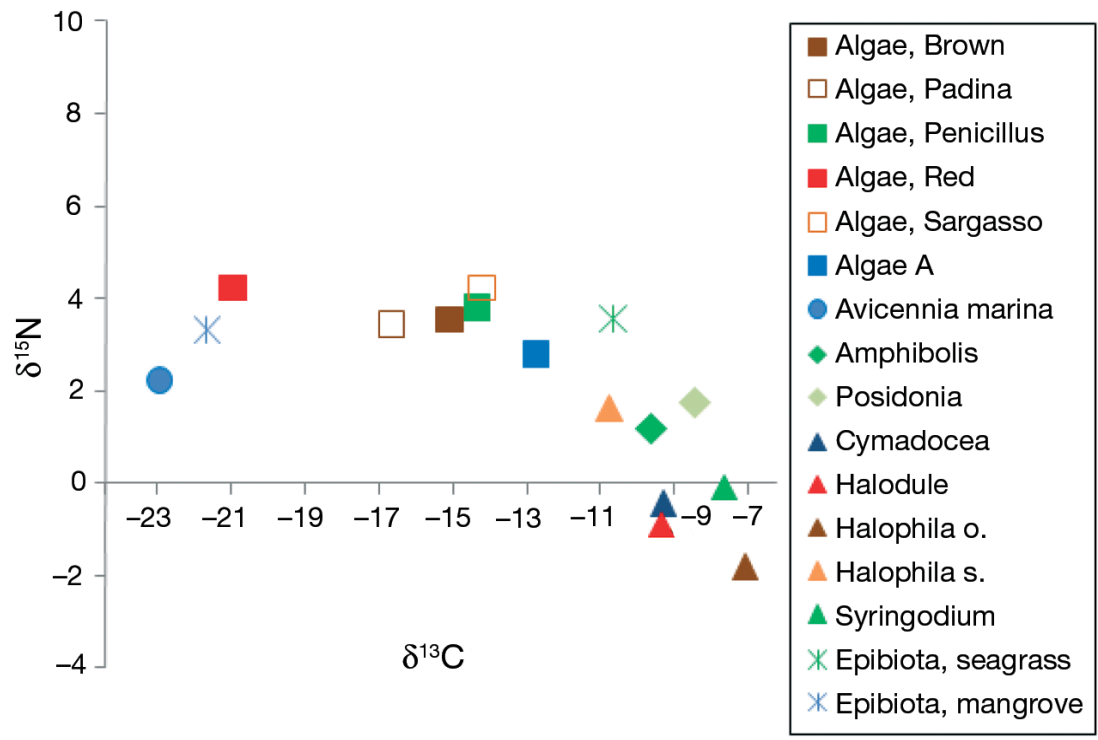

Fig. 3. Stable isotope biplot for primary producers from Shark Bay, Australia. Algae (ם): A = unknown calicified green alga, Brown = unknown brown alga, Penicillus $=$ Penicillus sp., Red $=$ unknown red alga, and Sargasso $=$ Sargassum spp. Mangrove (๑): Avicennia marina. Temperate seagrasses ( $\bullet$ ): Amphibolis $=$ Amphibolis antarctica, Posidonia $=$ Posidonia australis. Tropical seagrasses ( $\mathbf{\Delta})$ : Cymadocea $=$ Cymodocea angustata, Halodule $=$ Halodule uninervis, Halophila o. = Halophila ovalis, Halophila s. = H. spinulosa, Syringodium $=$ Syringodium isoetifolium. Epibiota $(\boldsymbol{*})$ : seagrass = epiphytes scraped from seagrass blades, mangrove = epibiota scraped from pneumatophores of Avicennia marina in mangrove creeks; SD for $\delta^{13} \mathrm{C}$ are omitted for simplicity, but range from 0.8 to $1.8 \%$ 


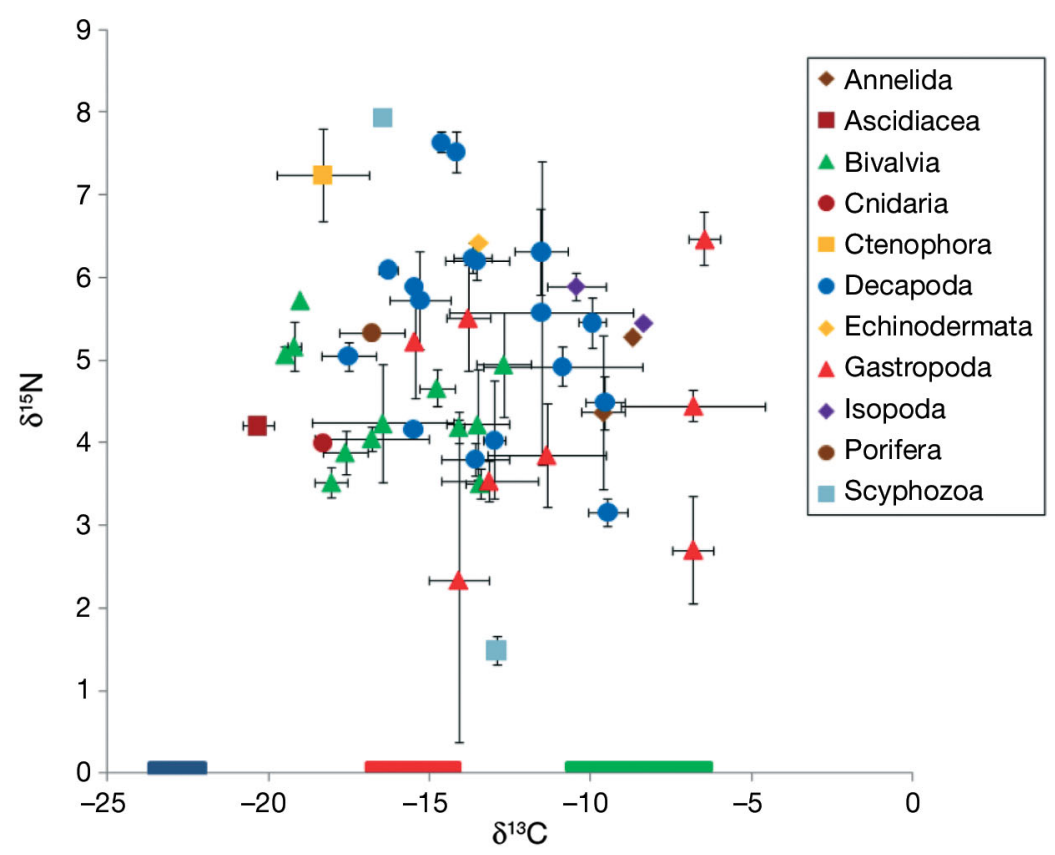

Fig. 4. Stable isotope biplots for invertebrate basal consumers from the study sites in Shark Bay, Australia. Means \pm SD. $\delta^{13} \mathrm{C}$ ranges: mangrove leaves and epibiota (blue line), marine algae (red line), and seagrass species (green line)
(Fig. 5A-E). This range for fish also exceeded the ranges of $\delta^{13} \mathrm{C}$ of most invertebrate basal consumers from mangrove habitats, suggesting some fish were moving across the system boundaries or feeding on imported food sources. Invertebrates from a pristine, tropical estuary in Queensland, Australia, appeared to incorporate productivity from mangrove and microphytobenthos in mangrove; these invertebrates were consumed by some fish (Abrantes \& Sheaves 2009). Mangrove habitat and more diverse mangrove species dominated that system; more research will be required to evaluate hypotheses about whether differences in the habitat mosaic or community composition account for apparent differences in trophic structure in Shark Bay.

Length was related to $\delta^{13} \mathrm{C}$ for 3 of the focal species of fish (Table 1). The influence of length depended on location for Atherinomorus vaigiensis, where the values of $\delta^{13} \mathrm{C}$ decreased much faster with increasing size at the sandy intertidal site of Monkey Mia than at GI. Larger Rhabdosargus sarba and Gerres subfasciatus tended be more enriched in ${ }^{13} \mathrm{C}$ when sites were considered together (although there was a suggestion of a decreasing slope for G. subfasciatus from DP).

Among-site differences in $\delta^{13} \mathrm{C}$ values were significant $(\mathrm{p}<0.05)$ for 4 species of fish and marginally significant $(0.05<\mathrm{p}<0.10)$ for 2 others (Table 1$)$. The $\delta^{13} \mathrm{C}$ value of Atherinomorus vaigiensis was less depleted in the Guichenault mangrove compared to Monkey Mia, with additional variation explained by differences in length as well as an interaction between site and length. $\delta^{13} \mathrm{C}$ was more depleted in larger fish at GI, but less depleted with size at Monkey Mia. Gerres subfas- ciatus also varied in $\delta^{13} \mathrm{C}$ where fish from the larger GI mangrove site were more ${ }^{13} \mathrm{C}$ depleted than the individuals from the smaller DP site. Fish captured in seagrass were not consistently different in $\delta^{13} \mathrm{C}$ compared to fish from mangrove sites, which is also inconsistent with a hypothesis of major contributions of Avicennia marina to food webs. In summary, several species of fish varied in $\delta^{13} \mathrm{C}$ values among sites separated by no more than $20 \mathrm{~km}$, but without consistent pattern among sites in the direction of this variation (Rayleigh's $Z$ 's: 0.36 to 2.74 , all $\mathrm{p}>0.05$ for 6 pairwise comparisons of sample sites).

Across sites, invertebrate consumers showed narrow ranges of $\delta^{15} \mathrm{~N}$ values; these varied $<2.5 \%$ for all invertebrates and by $<1.5 \%$ for $80 \%$ of taxa. Fish were characterized by greater variation in $\delta^{15} \mathrm{~N}$ values, which differed among sites for all the feeding guilds but were influenced by size in only a few cases (Fig. 5A-E, see Table A1 \& A2). The within-species $\delta^{15} \mathrm{~N}$ values differed among sites for 4 of 8 species of fish and marginal site effects were seen in Colurodontis paxmani (Table 2). Within species, the ranges of $\delta^{15} \mathrm{~N}$ were $1.9 \%$ (Pelates octolineatus), 1.2\% (Gerres subfasciatus), $1.7 \%$ (Craterocephalus mugiloides), and 0.8\% (Apogon rueppelli). Atherinomorus vaigiensis lacked site effects independent of differences in length and showed a marginal site-by-length interaction, with larger fish more enriched in ${ }^{15} \mathrm{~N}$ within GI (a site with a larger range of sizes for this species). Similarly, larger Amniataba caudavittata and C. paxmani were more enriched with ${ }^{15} \mathrm{~N}$. Variation in $\delta^{15} \mathrm{~N}$ among sites for A. caudavittata and A. vaigiensis were likely due to 
A Omnivores: Amniataba caudavittata $\mathbf{\square}$

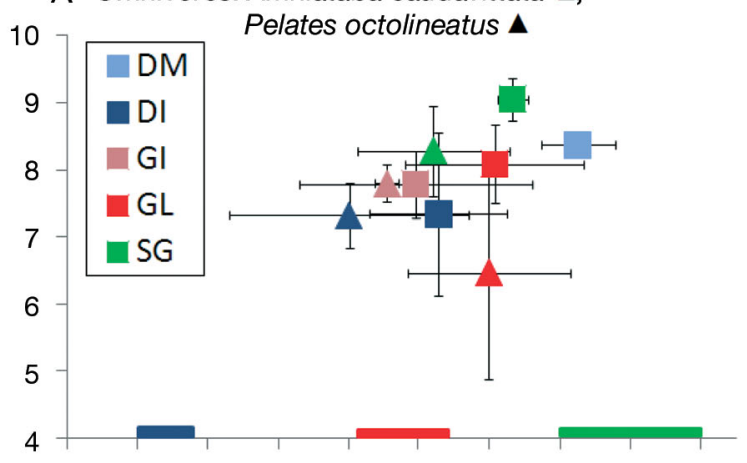

C Piscivores: Rhabdosargus sarba $\mathbf{\square}$, Tylosurus crocodilus $\mathbf{\Lambda}$,

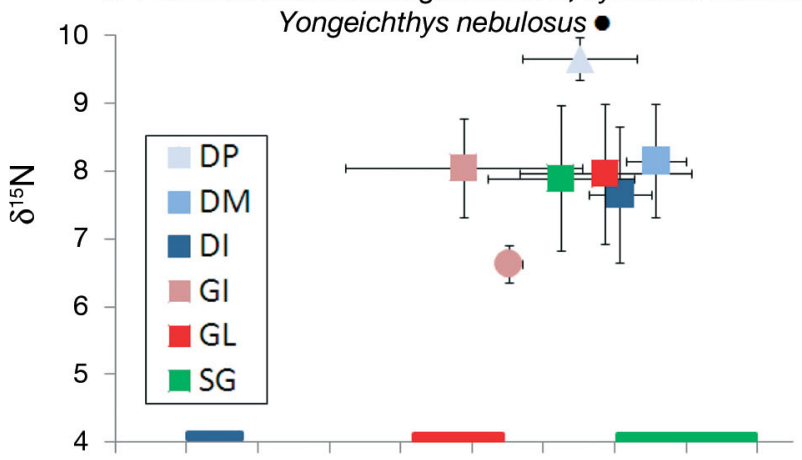

E Zoobenthivores: Gerres subfasciatus $₫$, Sillago burrus $\bullet$,

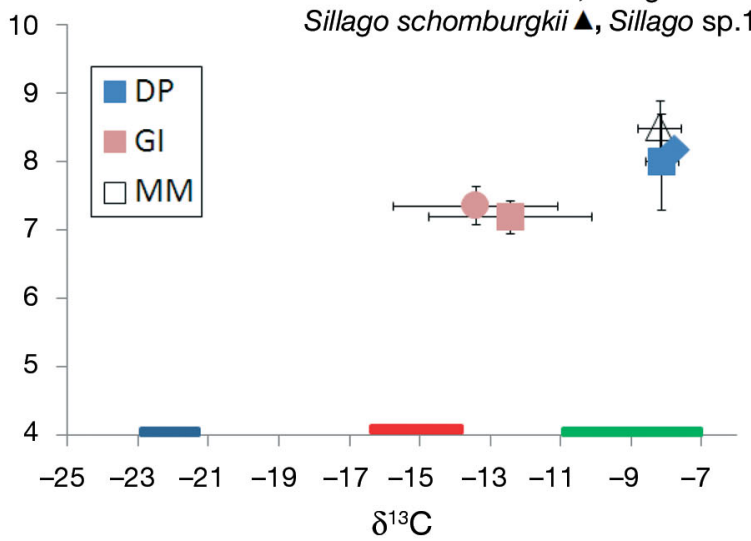

B Planktivores: Craterocephalus mugiloides $\mathbf{n}$,

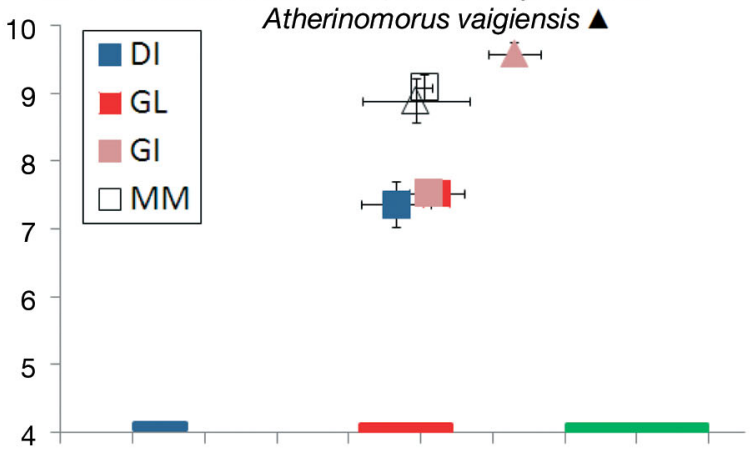

D Zoobenthivores: Colurodontis paxmani $\mathbf{\square}$,

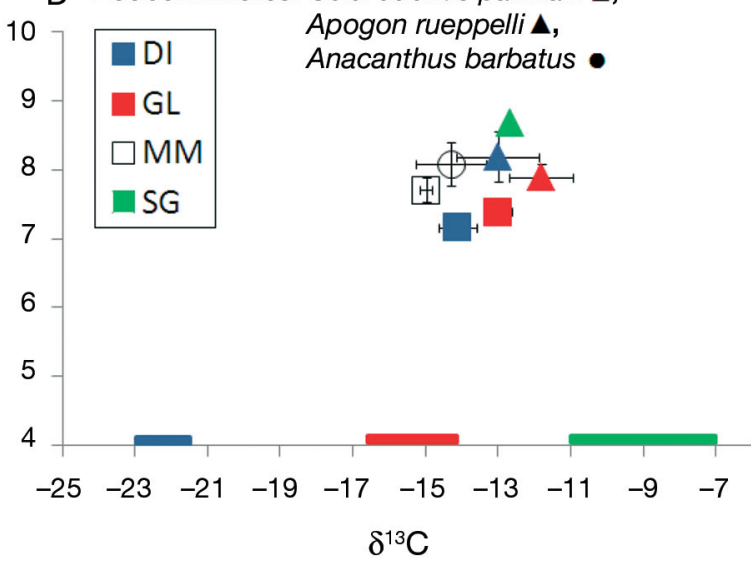

Fig. 5. Stable isotope biplots for fish species by feeding guild, for species captured from more than one of the study sites in Shark Bay, Australia. (A) Omnivores; (B) Planktivores; (C) Piscivores; (D \& E) Zoobenthivores. Means \pm SD. Symbols $=$ species within each panel. Colors = sampling sites: DP = Dubaut Point, $\mathrm{DM}=$ Dubaut Mouth, $\mathrm{DI}=$ Dubaut Interior, GI = Guichenault Interior, GL = Guichenault Lagoon, $\mathrm{SG}=$ seagrass beds, $\mathrm{MM}=$ Monkey Mia sandy intertidal zone. $\delta^{13} \mathrm{C}$ ranges: mangrove leaves and epibiota (blue line), marine algae (red line), and seagrass species (green line)

Table 1. Site and length effects on $\delta^{13} \mathrm{C}$ for species of fish found in 2 or more sites in Shark Bay, Australia, using ANCOVA. Site by length interaction was initially specified, but the interaction was dropped in reanalysis if the interaction was not significant $(p>0.10)$. Slope of length $-\delta^{13} C$ regression: indicated by $\beta$ for significant length effects. Two values of $\beta$ indicate slopes that varied with site. Data in bold indicate statistically significant parameters

\begin{tabular}{|c|c|c|c|c|c|c|c|c|c|}
\hline Species & $\mathrm{N}$ & $\mathrm{F}_{\text {Site }}$ & $\mathrm{p}_{\text {Site }}$ & $\mathrm{F}_{\text {Length }}$ & $\mathrm{p}_{\text {Length }}$ & $\beta$ & $\mathrm{F}_{\text {SitexLength }}$ & $\mathrm{p}_{\text {Site } \times \text { Length }}$ & $\mathrm{R}^{2}(\%)$ \\
\hline Amniataba caudavittata & 47 & 1.86 & 0.135 & 0.35 & 0.555 & & NS & NS & 17.5 \\
\hline Apogon rueppelli & 14 & 2.04 & 0.181 & 0.06 & 0.812 & & NS & NS & 9.0 \\
\hline Atherinomorus vaigiensis & 19 & 5.14 & 0.039 & 10.48 & 0.005 & $15.0,-11.4$ & 6.14 & 0.026 & 83.4 \\
\hline Colurodontis paxmani & 10 & 12.68 & 0.007 & 1.06 & 0.343 & & NS & NS & 72.3 \\
\hline Craterocephalus mugiloides & 19 & 2.72 & 0.085 & 0.04 & 0.851 & & NS & NS & 18.8 \\
\hline Gerres subfasciatus & 24 & 15.81 & 0.001 & 4.87 & 0.039 & 12.8 & NS & NS & 64.2 \\
\hline Pelates octolineatus & 65 & 2.59 & 0.061 & 0.27 & 0.605 & & NS & NS & 11.5 \\
\hline Rhabdosargus sarba & 44 & 8.02 & $<0.001$ & 4.82 & 0.034 & -10.8 & NS & NS & 39.5 \\
\hline
\end{tabular}


Table 2. Site and length effects on $\delta^{15} \mathrm{~N}$ for species of fish found in 2 or more sites in Shark Bay, Australia, using ANCOVA. Site by length interaction was initially specified, but the interaction was dropped in reanalysis if the interaction was not significant $(p>0.10)$. Slope of the length $-\delta^{13} \mathrm{C}$ regression is indicated by $\beta$ for significant length effects. Data in bold indicate statistically significant parameters

\begin{tabular}{|c|c|c|c|c|c|c|c|c|c|}
\hline Species & $\mathrm{N}$ & $\mathrm{F}_{\text {Site }}$ & $\mathrm{p}_{\text {Site }}$ & $\mathrm{F}_{\text {Length }}$ & $\mathrm{p}_{\text {Length }}$ & $\beta$ & $\mathrm{F}_{\text {SitexLength }}$ & $\mathrm{p}_{\text {SitexLength }}$ & $\mathrm{R}^{2}(\%)$ \\
\hline Amniataba caudavittata & 47 & 1.56 & 0.203 & 19.15 & 0.000 & 3.0 & NS & NS & 51.6 \\
\hline Apogon rueppelli & 14 & 4.76 & 0.035 & 0.39 & 0.546 & & NS & NS & 39.6 \\
\hline Atherinomorus vaigiensis & 19 & 1.40 & 0.255 & 6.55 & 0.022 & -3.1 & 3.32 & 0.089 & 80.1 \\
\hline Colurodontis paxmani & 10 & 3.52 & 0.097 & 5.55 & 0.057 & & NS & NS & 41.1 \\
\hline Craterocephalus mugiloides & 19 & 6.05 & 0.007 & 0.72 & 0.411 & & NS & NS & 90.2 \\
\hline Gerres subfasciatus & 24 & 11.15 & 0.003 & 0.02 & 0.877 & & NS & NS & 36.3 \\
\hline Pelates octolineatus & 65 & 6.57 & 0.001 & 0.49 & 0.488 & & NS & NS & 31.8 \\
\hline Rhabdosargus sarba & 44 & 0.30 & 0.876 & 0.18 & 0.676 & & NS & NS & 0.0 \\
\hline
\end{tabular}

differences in sizes among sites. Comparing sites, the range of $\delta^{15} \mathrm{~N}$ values for all fish was narrow at $1.46 \%$ $\left(F=9.40, \mathrm{p}<0.01, \mathrm{R}^{2}=15.2 \%\right)$.

\section{DISCUSSION}

Two major patterns emerge from our results. Stable isotope values of carbon suggest minor contributions, at most, from mangrove trees to secondary productivity of small fish using fringing mangrove habitat in Shark Bay. Also, within species of fish, stable isotope values can vary over spatial scales as localized as hundreds of meters. We structure our discussion around these 2 themes.

\section{Mangrove contributions to fish productivity}

Although fish and invertebrates inhabit the fringing mangrove habitat, they are not deriving a substantial proportion of their biomass from Avicennia marinabased trophic pathways or its pneumatophores-associated epibiota. This interpretation is consistent with findings in other systems that have pointed out the relatively low consumer reliance on mangrove productivity (Fry \& Ewel 2003, Layman 2007). In the almost pristine ecosystem of Shark Bay, invertebrates ( -15.7 to $-9.34 \%$ o) and fish $\left(-14.9\right.$ to $-7.8 \%$ ) tend to have $\delta^{13} \mathrm{C}$ values that are more consistent with those of algae and/or seagrass. Blaber (2007) suggested that fish might benefit from mangrove habitats by feeding on mangrove-associated epiphytes rather than on mangrove-derived production, but in our study epiphytes tended to have the same signature as mangrove leaves. Other potential sources of primary productivity in fringing mangroves are benthic microalgae (especially diatoms), pelagic phytoplankton, macroalgae, and detritus from seagrass beds imported with tides. Although our study was not designed to distinguish which of these form the base of fish trophic systems, our results clearly support the hypothesis that fish rely on mangroves for a reason or reasons other than direct feeding pathways.

Numerous fish species inhabiting mangroves migrate between mangrove and adjacent habitats (Nagelkerken \& van der Velde 2004, Sheaves 2005, Hammerschlag-Peyer \& Layman 2010). In Shark Bay, most species of fish caught in fringing mangrove habitats also inhabit seagrass and sand flat habitats suggesting that individual fishes studied herein may move frequently between habitats in this system (Black et al. 1990, Linke et al. 2001, Travers \& Potter 2002, Heithaus 2004). Alternatively, basal resource pools can be readily transported among habitat types in coastal systems (Melville \& Connolly 2003, Connolly et al. 2005), and fish may remain within mangrove-dominated habitats and feed on imported resources.

The expected direction of nutrient movement in mangrove-seagrass complexes has been somewhat controversial. The 'outwelling hypothesis' (Odum \& Heald 1975) proposed that carbon from mangrove productivity would be exported from these coastal systems to adjacent offshore systems, but most tests of the hypothesis have found the opposite; nutrients tend to be transported from seagrass beds in to mangrove habitats (Lee 1995, Bouillon et al. 2008, Kristensen et al. 2008, but see Sheaves \& Molony 2000). Some riverine and basin mangroves may substantially support the food webs of adjacent habitats (Thimdee et al. 2008), but fringing mangroves are much less likely to provide such a major carbon subsidy (Faunce \& Layman 2009). This is particularly true for Shark Bay, where fringing mangroves are small in stature, represent a small fraction of the total habitat, and fish have access to rich feeding opportunities in adjacent seagrass beds.

If food from the most common primary producers is not a major benefit of occupying these fringing mangroves, why are so many fish in this habitat? The most 
obvious explanation is protection from larger predators, as fringing mangroves also provide the benefit of predator avoidance (Meynecke et al. 2007, Platell et al. 2007). Recent studies have provided multiple lines of evidence that mangroves are critical for predator protection, instead of the commonly held belief that they also provide additional food resources (Grol et al. 2008, Dorenbosch et al. 2009). The potential impact of fringing mangroves is illustrated by comparing the density of juvenile sharks from seagrass and unvegetated nursery areas that are either close or far from the Guichenault site; nurseries close to mangroves had 2- to 10-fold more sharks (White \& Potter 2004). Protective benefits were observed for fish moving in and out of mangrove creeks in Queensland, Australia (Meynecke et al. 2008), and for Acanthopagrus latus in Shark Bay, Australia (Platell et al. 2007). These observations support additional studies on differences in predation rates among habitats.

\section{Variation in stable isotope values}

We observed differences in stable isotopic values within and between species, between habitats, and between sample sites for the same habitat. Hypotheses for ecological mechanisms accounting for such variation include body size (within species), different feeding niches (within or between species), variation in basal resource values (between sample sites), and landscape variation (the extent of mangrove in the local habitat mosaic).

The small influence of body size on stable isotopic values for most species of fish was consistent with recent findings that some coastal fish vary in habitat use independent of body size (Hammerschlag-Peyer \& Layman 2010 and references therein). Many studies suggested widespread correlations between fish size and habitat use and feeding (e.g. Minns 1995, Gu et al. 1996, Shannon et al. 2001, Barnes et al. 2008, Chassot et al. 2008), but fish size was not a major influence in our study. The influence of size may decline with increasing complexity of food webs where body size of primary consumer taxa is highly variable (Layman et al. 2005). Additionally, when fish can choose among several alternative habitat types and food resources, individual variation in behavior may mask the population-level influences of body size (HammerschlagPeyer \& Layman 2010).

Spatial variation in diet was suggested by differences in $\delta^{13} \mathrm{C}$ among sites that were statistically detectable for areas just hundreds of meters apart. In parallel with our observations of fine-scale variation in stable isotope values, studies of Pelates octolineatus' stomach contents by Sanchez-Jerez et al. (2002) indi- cated variation in diet within scales of hundreds of meters that reflected differences in the abundance of prey among the studied seagrass habitats. For Amniataba caudavittata at Dubaut Creek, the $\delta^{13} \mathrm{C}$ value was different at the mouth of the creek, compared to interior sampling locations. These patterns are also consistent with variation in primary consumer isotope variation across a scale of hundreds of meters in coastal systems of the Bahamas, a similar marinedominated, oligotrophic, coastal system (Hammerschlag-Peyer \& Layman 2010).

In general, we did not observe consistent patterns of variation in carbon sources associated with differences in the habitat mosaic; $\delta^{13} \mathrm{C}$ did not vary systematically with different mangrove habitat size or the proportions of the habitat mosaics that were seagrass and mangroves. Further studies would be required to determine whether fine-scale variation in habitat mosaics lead to predictable differences in trophic structure. The low contribution of mangroves and their epibiota to trophic webs, however, suggests that in restricted fringing mangrove systems like those of Shark Bay there may be relatively little variation across a range of habitat mosaics. In addition, any subtle variation in isotope values based on habitat mix may be minimized by the localized spatial variation in diets observed for species.

Much has been written about non-ecological sources of variation in stable isotope values. Differences in fractionation within individuals among tissues, and between individuals within the same environments can cause variation in stable isotopic values (Barnes et al. 2008, Martínez del Rio et al. 2009), as can changes in the structure of the food web beneath a consumer of interest (Post 2002, Layman et al. 2007). Within a population, laboratory studies show that even individuals consuming exactly the same food can vary in stable isotope values; for $\delta^{15} \mathrm{~N}$, laboratory-reared wild bass showed coefficients of variation (CV) of $2.6 \%$, which was equivalent to the $\mathrm{CV}$ for some wild-caught bass populations (Barnes et al. 2008). In their study, the CV for $\delta^{13} \mathrm{C}$ for equilibrated laboratory-reared bass was $1.2 \%$ while wild-caught populations $\mathrm{CV}$ was $14 \%$ overall. In our study, CV's ranged from 5.0 to $26.3 \%$ (mean: $13.8 \%$ ) for $\delta^{13} \mathrm{C}$ and 3.3 to $11.6 \%$ (mean: $6.7 \%$ ) for $\delta^{15} \mathrm{~N}$, greatly exceeding variability expected from internal mechanisms. Further, we minimized differences from non-trophic sources by using only muscle tissue from fish and by sampling within a narrow interval of time.

In conclusion, even though vegetation density suggests high primary productivity in mangrove communities, on a local scale there is little evidence of mangroves directly supporting secondary production of consumers. We also provide additional data that 
emphasize the multiple spatial scales at which consumer isotope values can vary: a source of variation that must be accounted for in coastal marine systems.

Acknowledgements. R. Black and A. Brearley (University of Western Australia) helped with identifications of invertebrates. We thank S. Morrison (Western Australian Museum) for assistance in identifying fish. We thank the staff of CALM at Monkey Mia for their logistic support. This research was supported by grants from the National Science Foundation (OCE0526065, OCE0620409, OCE0745606, OCE0746164, and by funding from Kenyon College to E.R.H. This is contribution \#46 from the Shark Bay Ecosystem Research Project.

\section{LITERATURE CITED}

Abrantes K, Sheaves M (2009) Food web structure in a nearpristine mangrove area of the Australian wet tropics. Estuar Coast Shelf Sci 82:597-607

Barnes C, Jennings S, Polunin NVC, Lancaster JE (2008) The importance of quantifying inherent variability when interpreting stable isotope field data. Oecologia 155:227-235

Blaber SJM (2007) Mangroves and fishes: issues of diversity, dependence, and dogma. Bull Mar Sci 80:457-472

Black R, Robertson AI, Peterson CH, Peterson NM (1990) Fishes and benthos of near-shore seagrass and sandflat habitats at Monkey Mia Shark Bay, Western Australia. In: Berry PF, Bradshaw SD, Wilson BR (eds) Research in Shark Bay. Report of the France-Australe Bicentenary Expedition Committee. West Aus Mus, Perth, p 245-261

Bouillon S, Connolly RM, Lee SY (2008) Organic matter exchange and cycling in mangrove ecosystems: recent insights from stable isotope studies. J Sea Res 59:44-58

Chassot E, Rouyer T, Trenkel VM, Gascuel D (2008) Investigating trophic-level variability in Celtic Sea fish predators. J Fish Biol 73:763-781

Connolly RM, Gorman D, Guest MA (2005) Movement of carbon among estuarine habitats and its assimilation by invertebrates. Oecologia 144:684-691

Dorenbosch M, Grol MGG, de Groene A, van der Velde G, Nagelkerken I (2009) Piscivore assemblages and predation pressure affect relative safety of some back-reef habitats for juvenile fish in a Caribbean bay. Mar Ecol Prog Ser 379:181-196

Duffy JE (2006) Biodiversity and the functioning of ecosystems. Mar Ecol Prog Ser 311:233-250

Elliott M, Whitfield AK, Potter IC, Blaber SJM, Cyrus DP, Nordlie FG, Harrison TD (2007) The guild approach to categorizing estuarine fish assemblages: a global review. Fish Fish 8:241-268

Ewel K, Twilley R, Ong J (1998) Different kinds of mangrove forests provide different goods and services. Glob Ecol Biogeogr 7:83-94

Faunce CH, Layman CA (2009) Sources of variation that affect perceived nursery function of mangroves. In: Nagelkerken I (ed) Ecological connectivity among tropical coastal ecosystems. Springer Science + Business Media B.V., New York, NY, p 401-421

Faunce CH, Serafy JE (2006) Mangroves as fish habitat: 50 years of field studies. Mar Ecol Prog Ser 318:1-18

Froese F, Pauly D (2009) FishBase, available at www. fishbase.org

Fry B, Ewel KC (2003) Using stable isotopes in mangrove fisheries research: a review and outlook. Isotopes Environ Health Stud 39:191-196
Grol MGG, Dorenbosch M, Kokkelmans EMG, Nagelkerken I (2008) Mangroves and seagrass beds do not enhance growth of early juveniles of a coral reef fish. Mar Ecol Prog Ser 366:137-146

> Gu B, Schelske CL, Hoyer MV (1996) Stable isotopes of carbon and nitrogen as indicators of diet and trophic structure of the fish community in a shallow hypereutrophic lake. J Fish Biol 49:1233-1243

> Hammerschlag-Peyer CP, Layman CA (2010) Specialization in individual-level movement patterns of snapper in Bahamian wetlands. Mar Ecol Prog Ser 415:211-220

Heithaus MR (2004) Fish communities of subtropical seagrass meadows and associated habitats in Shark Bay, Western Australia. Bull Mar Sci 75:79-99

Hoese DF, Bray DJ, Paxon JR, Gerald RA (2007) Fishes. In Beasley OL, Wells A (eds) Zoological catalogue of Australia, Vol 35, Parts 1-3. ABRS \& CSIRO Publishing, Collingswood

Kristensen E, Bouillon S, Dittmar T, Marchand C (2008) Organic carbon dynamics in mangrove ecosystems: a review. Aquat Bot 89:201-219

Laegdsgaard P, Johnson C (2001) Why do juvenile fish utilise mangrove habitats? J Exp Mar Biol Ecol 257:229-253

Layman CA (2007) What can stable isotope ratios reveal about mangroves as fish habitat? Bull Mar Sci 80:513-527

Layman CA, Winemiller KO, Arrington DA, Jepsen DB (2005) Body size and trophic position in a diverse tropical food web. Ecology 86:2530-2535

> Layman CA, Quattrochi JP, Peyer CM, Allgeier JE (2007) Niche width collapse in a resilient top predator following ecosystem fragmentation. Ecol Lett 10:937-944

> Lee SY (1995) Mangrove outwelling: a review. Hydrobiologia 295:203-212

> Linke TE, Platell ME, Potter IC (2001) Factors influencing the partitioning of food resources among six fish species in a large embayment with juxtaposing bare sand and seagrass habitats. J Exp Mar Biol Ecol 266:193-217

> Loneragan NR, Bunn SE, Kellaway DM (1997) Are mangroves and seagrasses sources of organic carbon for penaeid prawns in a tropical Australian estuary? A multiple stableisotope study. Mar Biol 130:289-300

Lugendo BR, Nagelkeren I, Kruitwagen G, van der Velde G, Mgaya YD (2007) Relative importance of mangroves as feeding habitats for fishes: a comparison between mangrove habitats with different settings. Bull Mar Sci 80: 497-512

Luo J, Serafy JE, Sponaugle S, Teare PB, Kieckbusch D (2009) The movement of gray snapper Lutjanus griseus among subtropical seagrass, mangrove, and coral reef habitats. Mar Ecol Prog Ser 380:255-269

Mallela J, Harrod C (2008) $\delta \mathrm{C}-13$ and $\delta \mathrm{N}-15$ reveal significant differences in the coastal foodwebs of the seas surrounding Trinidad and Tobago. Mar Ecol Prog Ser 368:41-51

- Martínez del Rio C, Wolf N, Carleton SA, Gannes LZ (2009) Isotopic ecology ten years after a call for more laboratory experiments. Biol Rev Camb Philos Soc 84:91-111

Melville AJ, Connolly RM (2003) Spatial analysis of stable isotope data to determine primary sources of nutrition for fish. Oecologia 136:499-507

Mendoza-Carranza M, Hoeinghaus DJ, Garcia AM, RomeroRodriguez Á (2010) Aquatic food webs in mangrove and seagrass habitats of Centla Wetland, a Biosphere Reserve in southeastern Mexico. Neotrop Ichthyol 8:171-178

Meynecke JO, Lee SY, Duke NC, Warnken J (2007) Relationships between estuarine habitats and coastal fisheries in Queensland, Australia. Bull Mar Sci 80:773-793

Meynecke JO, Poole GC, Werry J, Lee SY (2008) Use of PIT 
tag and underwater video recording in assessing estuarine fish movement in a high intertidal mangrove and salt marsh creek. Estuar Coast Shelf Sci 79:168-178

Minns CK (1995) Allometry of home-range size in lake and river fishes. Can J Fish Aquat Sci 52:1499-1508

Nagelkerken I (2009) Ecological connectivity among tropical coastal ecosystems. Springer Science + Business Media B. V., New York, NY

> Nagelkerken I, van der Velde G (2004) Are Caribbean mangroves important feeding grounds for juvenile reef fish from adjacent seagrass beds? Mar Ecol Prog Ser 274: $143-151$

Nagelkerken I, Blaber SJM, Bouillon S, Green P and others (2008) The habitat function of mangroves for terrestrial and marine fauna: a review. Aquat Bot 89:155-185

Odum WE, Heald EJ (1975) The detritus-based food web of an estuarine mangrove community. In: Cronin LE (ed) Estuarine research, Vol 1. Academic Press, New York, NY, p 265-286

Phillips DL, Gregg JW (2003) Source partitioning using stable isotopes: coping with too many sources. Oecologia 136: 261-269

Platell ME, Ang SA, Hesp SA, Potter IC (2007) Comparisons between the influences of habitat, body size and season on the dietary composition of the sparid Acanthopagrus latus in a large marine embayment. Estuar Coast Shelf Sci 72 : 626-634

Post DM (2002) Using stable isotopes to estimate trophic position: models, methods, and assumptions. Ecology 83: 703-718

Post DM, Layman CA, Arrington DA, Takimoto G, Quattrochi J, Montana CG (2007) Getting to the fat of the matter: models, methods and assumptions for dealing with lipids in stable isotope analyses. Oecologia 152:179-189

Sakabe R, Lyle JM (2010) The influence of tidal cycles and freshwater inflow on the distribution and movement of an estuarine resident fish Acanthopagrus butcheri. J Fish Biol 77:643-660

Sanchez-Jerez P, Gillanders BM, Kingsford MJ (2002) Spatial variation in abundance of prey and diet of trumpeter (Pelates sexlineatus: Teraponidae) associated with Zostera capricorni seagrass meadows. Austral Ecol 27:200-210
Schmidt SN, Olden JD, Solomon CT, Vander Zanden MJ (2007) Quantitative approaches to the analysis of stable isotope food web data. Ecology 88:2793-2802

Shannon JP, Blinn DW, Haden GA, Benenati EP, Wilson KP (2001) Food web implications of $\delta \mathrm{C}-13$ and $\delta$ N-15 variability over $370 \mathrm{~km}$ of the regulated Colorado River, USA. Isotopes Environ Health Stud 37:179-191

Sheaves M (2005) Nature and consequences of biological connectivity in mangrove systems. Mar Ecol Prog Ser 302: 293-305

Sheaves M (2009) The consequences of ecological connectivity: the example of the coastal ecosystem mosaic. Mar Ecol Prog Ser 391:107-115

Sheaves M, Molony B (2000) Short-circuit in the mangrove food chain. Mar Ecol Prog Ser 199:97-109

Thimdee W, Deein G, Nakayama N, Suzuki Y, Matsunaga K (2008) d13C and d15N indicators of fish and shrimp community diet and trophic structure in a mangrove ecosystem in Thailand. Wetlands Ecol Manage 16:463-470

Travers MJ, Potter IC (2002) Factors influencing the characteristics of fish assemblages in a large subtropical marine embayment. J Fish Biol 61:764-784

UNEP, World Conservation Monitoring Centre (2008) Shark Bay, Western Australia. United Nations Environment Programme, World Conservation Monitoring Centre, available at: www.unep-wcmc.org/protected_areas/data/ wh/sharkbay.html

Unsworth RKF, Wylie E, Smith DJ, Bell JJ (2007) Diel trophic structuring of seagrass bed fish assemblages in the Wakatobi Marine National Park, Indonesia. Estuar Coast Shelf Sci 72:81-88

Walker DI (1990) Seagrass in Shark Bay, Western Australia. In: Berry PF, Bradshaw SD, Wilson BR (eds) Research in Shark Bay. Report of the France-Australe Bicentenary Expedition Committee. West Aus Mus, Perth, p 101-106

- Werry J, Lee SY (2005) Grapsid crabs mediate link between mangrove litter production and estuarine planktonic food chains. Mar Ecol Prog Ser 293:165-176

- White WT, Potter IC (2004) Habitat partitioning among four elasmobranch species in nearshore, shallow waters of a subtropical embayment in Western Australia. Mar Biol 145:1023-1103 
Appendix 1. Table A1. Lengths and sample sizes for fish used for stable isotope analysis from Shark Bay, Western Australia. Sites: DP = Dubaut Point, DM = Dubaut Mouth, DI = Dubaut Interior, GL = Guichenault Lagoon, GI = Guichenault Interior, SG = subtidal seagrass beds, $\mathrm{MM}=$ intertidal sandy fringe at Monkey Mia. Sample size for each cell indicated within parentheses. ${ }^{* * *}$ ANOVA $\mathrm{p}<0.001,{ }^{* *} \mathrm{p}<0.01,{ }^{*} \mathrm{p}<0.05$; NS $=\mathrm{p}>0.10$. Comparisons of length are based on Tukey 95\% simultaneous confidence intervals (the null hypothesis cannot be rejected for sites sharing a superscript)

\begin{tabular}{|c|c|c|c|c|c|c|c|c|}
\hline \multirow[t]{2}{*}{ Species } & \multirow[b]{2}{*}{ Common name } & \multirow[b]{2}{*}{$\mathrm{DP}$} & \multirow{2}{*}{$\overline{\mathrm{DM}}$} & \multicolumn{2}{|c|}{ Length $(\mathrm{mm}) \pm \mathrm{SE}(\mathrm{n})-$} & \multirow[b]{2}{*}{ GI } & \multirow[b]{2}{*}{$\mathrm{SG}$} & \multirow[b]{2}{*}{ MM } \\
\hline & & & & DI & GL & & & \\
\hline $\begin{array}{l}\text { Amniataba } \\
\text { caudavittata }\end{array}$ & $\begin{array}{l}\text { Yellowtail } \\
\text { trumpeter }^{* * *}\end{array}$ & & $\begin{array}{c}104.0 \pm \\
4.3(3)^{\mathrm{a}, \mathrm{b}}\end{array}$ & $\begin{array}{c}75.3 \pm \\
4.6(13)^{\mathrm{a}}\end{array}$ & $\begin{array}{c}137.2 \pm \\
10.1(12)^{\mathrm{a}}\end{array}$ & $\begin{array}{c}83.3 \pm \\
4.0(12)^{\mathrm{a}, \mathrm{b}}\end{array}$ & $\begin{array}{l}186.6 \pm \\
11.1(7)^{\mathrm{C}}\end{array}$ & \\
\hline Apogon rueppelli & $\begin{array}{l}\text { Gobbleguts } \\
\text { NS }\end{array}$ & & & $\begin{array}{c}61.2 \pm \\
7.87(4)\end{array}$ & $\begin{array}{c}59.0 \pm \\
2.52(9)\end{array}$ & & $70.0(1)$ & \\
\hline $\begin{array}{l}\text { Atherinomorus } \\
\text { vaigiensis }\end{array}$ & $\begin{array}{l}\text { Ogilby's } \\
\text { hardyhead }^{* * *}\end{array}$ & & & & & $\begin{array}{c}136.3 \pm \\
3.1(10)^{\mathrm{b}}\end{array}$ & & $\begin{array}{c}78.1 \pm \\
3.1(10)^{\mathrm{a}}\end{array}$ \\
\hline $\begin{array}{l}\text { Colurodontis } \\
\text { paxmani }\end{array}$ & $\begin{array}{l}\text { Paxman's leather- } \\
\text { jacket NS }\end{array}$ & & & $\begin{array}{l}51.0 \pm \\
5.0(2)\end{array}$ & & $\begin{array}{l}49.5 \pm \\
4.5(2)\end{array}$ & $\begin{array}{l}55.7 \pm \\
0.3(6)\end{array}$ & \\
\hline $\begin{array}{l}\text { Craterocephalus } \\
\text { mugiloides }\end{array}$ & $\begin{array}{l}\text { Spotted } \\
\text { hardyhead }^{* * *}\end{array}$ & & & $\begin{array}{l}36.1 \pm \\
2.1(5)^{\mathrm{a}}\end{array}$ & $\begin{array}{c}33.5 \pm \\
0.7(5)^{\mathrm{a}}\end{array}$ & $\begin{array}{c}35.6 \pm \\
0.5(5)^{\mathrm{a}}\end{array}$ & & $\begin{array}{l}57.5 \pm \\
2.0(4)^{\mathrm{b}}\end{array}$ \\
\hline $\begin{array}{l}\text { Gerres } \\
\text { subfasciatus }\end{array}$ & $\operatorname{Roach}^{* * *}$ & $\begin{array}{c}79.8 \pm \\
3.5(10)^{\mathrm{b}}\end{array}$ & & & & $\begin{array}{l}66.57 \pm \\
2.5(14)^{\mathrm{a}}\end{array}$ & & \\
\hline $\begin{array}{l}\text { Pelates } \\
\quad \text { octolineatus }\end{array}$ & $\begin{array}{l}\text { Striped } \\
\text { trumpeter }\end{array}$ & & & $\begin{array}{l}64.8 \pm \\
6.4(6)^{\mathrm{b}}\end{array}$ & $\begin{array}{c}92.2 \pm \\
14.8(4)^{\mathrm{c}}\end{array}$ & $\begin{array}{c}37.7 \pm \\
1.2(10)^{\mathrm{a}}\end{array}$ & $\begin{array}{l}216.4 \pm \\
4.4(45)^{\mathrm{d}}\end{array}$ & \\
\hline $\begin{array}{l}\text { Rhabdosargus } \\
\text { sarba }\end{array}$ & Tarwhine $^{* * *}$ & & $\begin{array}{c}115.2 \pm \\
13.2(5)^{\mathrm{a}}\end{array}$ & $\begin{array}{l}103.8 \pm \\
7.2(5)^{\mathrm{a}}\end{array}$ & $\begin{array}{l}107.2 \pm \\
4.1(19)^{\mathrm{a}}\end{array}$ & $\begin{array}{l}101.1 \pm \\
5.7(11)^{\mathrm{a}}\end{array}$ & $\begin{array}{l}160.0 \pm \\
7.1(4)^{\mathrm{b}}\end{array}$ & \\
\hline Sillago burrus & $\begin{array}{l}\text { Western trumpeter } \\
\text { Whiting NA }\end{array}$ & & & & & $\begin{array}{c}94.7 \pm \\
1.3(10)\end{array}$ & & \\
\hline $\begin{array}{l}\text { Sillago } \\
\quad \text { schomburgkii }\end{array}$ & $\begin{array}{l}\text { Yellowfin } \\
\text { whiting NA }\end{array}$ & & & & & & & $\begin{array}{c}97.0 \pm \\
11.0(2)\end{array}$ \\
\hline Sillago sp. & Whiting sp. NA & $\begin{array}{c}97.4 \pm \\
9.5(10)\end{array}$ & & & & & & \\
\hline $\begin{array}{l}\text { Tylosurus } \\
\text { crocodilus }\end{array}$ & $\begin{array}{l}\text { Slender } \\
\text { longtom NA }\end{array}$ & $\begin{array}{c}279.7 \pm \\
2.3(3)\end{array}$ & & & & $259.0(1)$ & & \\
\hline $\begin{array}{c}\text { Yongeichthys } \\
\text { nebulosus }\end{array}$ & Shadow goby NA & & & & & $\begin{array}{l}52.6 \pm \\
2.3(9)\end{array}$ & & \\
\hline
\end{tabular}


Appendix 2. Table A2. Taxa and sample sizes (N) for invertebrates contributing to stable isotope values for primary consumers (see Fig. 4). N: number of individuals; In parentheses: number of independent measures of stable isotope values where individuals were aggregated to obtain sufficient tissue for analysis. Sites: DI $=$ Dubaut Interior, GL = Guichenault Lagoon, GI = Guichenault Interior, $\mathrm{SG}=$ subtidal seagrass beds, MM = intertidal sandy fringe at Monkey Mia

\begin{tabular}{|c|c|c|c|c|c|}
\hline Taxon & Taxon species/morphospecies & $\mathrm{N}$ & Mean $\delta \mathrm{C}$ & Mean $\delta N$ & Sites \\
\hline Annelida & Tube worm sp 1 & 4 & -8.43 & 4.37 & $\mathrm{SG}$ \\
\hline Annelida & Tube worm sp 2 & $20(1)$ & -7.86 & 6.21 & SG \\
\hline Annelida & Tube worm sp 3 & $40(2)$ & -8.20 & 5.27 & $\mathrm{SG}$ \\
\hline Ascidiacea & Ascidian sp 1 & 2 & -20.33 & 4.21 & SG \\
\hline Bivalvia & Anomalocardia squamosa & 7 & -14.09 & 4.19 & GI \\
\hline Bivalvia & Brachiodontus ustulatus & 10 & -13.43 & 3.51 & DI \\
\hline Bivalvia & Callista impar & 3 & -14.77 & 4.66 & SG \\
\hline Bivalvia & Chlamys asperrima & 6 & -19.21 & 5.17 & SG \\
\hline Bivalvia & Modiolus sp. & 10 & -18.04 & 3.81 & SG \\
\hline Bivalvia & Pectinidae sp 1 & 3 & -19.48 & 5.07 & SG \\
\hline Bivalvia & Pennatulacea sp 1 & 1 & -19.01 & 5.73 & SG \\
\hline Bivalvia & Pinna cf. mundula & 10 & -16.79 & 4.05 & GL, SG \\
\hline Bivalvia & Pitar citrina & 20 & -13.51 & 4.22 & DI, GI, MM \\
\hline Bivalvia & Placamen berryi & 11 & -12.69 & 4.95 & DI, GL, MM \\
\hline Bivalvia & Saccostrea ?commercialis & 28 & -16.45 & 4.24 & GI, GM, SG \\
\hline Bivalvia & Strombus sp & 3 & -13.94 & 2.33 & SG \\
\hline Decapoda & Callinectes sp 1 & 3 & -12.97 & 6.22 & $\mathrm{MM}$ \\
\hline Decapoda & Callinectes sp 2, adult & 6 & -10.42 & 5.25 & $\mathrm{MM}, \mathrm{SG}$ \\
\hline Decapoda & Callinectes sp 2, juvenile & 5 & -9.96 & 5.45 & MM \\
\hline Decapoda & Clibanarius sp. & 6 & -10.87 & 4.92 & GI, GL \\
\hline Decapoda & Eurybrachyura sp 1 & 3 & -13.58 & 3.80 & GL \\
\hline Decapoda & Gafrarium intermedium & 12 & -12.99 & 4.03 & DI, GI \\
\hline Decapoda & Gallitheid sp A & 3 & -17.53 & 5.05 & SG \\
\hline Decapoda & Gallitheid sp B & 4 & -15.50 & 4.16 & SG \\
\hline Decapoda & Malacostraca sp 1 & $75(3)$ & -15.3 & 5.72 & SG \\
\hline Decapoda & Malacostraca sp 2 & (6) & -13.53 & 6.21 & DI, GI \\
\hline Decapoda & Malacostraca sp 3 & (3) & -15.48 & 5.89 & SG \\
\hline Decapoda & Malacostraca sp 4 & (3) & -15.71 & 5.89 & SG \\
\hline Decapoda & Malacostraca sp 5 & (3) & -14.17 & 7.52 & SG \\
\hline Decapoda & Mictrys ?longicarpus & 3 & -9.47 & 6.47 & MM \\
\hline Decapoda & Palaeomonetid sp 1 & 3 & -9.55 & 4.49 & SG \\
\hline Decapoda & Palaeomonetid sp 2 & 3 & -13.66 & 6.23 & GL \\
\hline Decapoda & Scylla sp & 10 & -11.54 & 6.31 & MM \\
\hline Echinodermata & Asteroidea sp 1 & 1 & -13.48 & 6.42 & $\mathrm{SG}$ \\
\hline Gastropoda & Calthalotia cf. mudulata & 5 & -13.80 & 5.51 & SG \\
\hline Gastropoda & Clypeomorus bifasciata & 3 & -13.15 & 3.53 & GI \\
\hline Gastropoda & Nassarius clarus & 5 & -6.47 & 6.47 & MM \\
\hline Gastropoda & Philine angasi & 5 & -6.82 & 4.44 & MM \\
\hline Gastropoda & Pyrene bidentata & $50(5)$ & -15.46 & 5.22 & GL, SG \\
\hline Gastropoda & Terebralia semistriata & 25 & -11.36 & 3.81 & DI, DM, GI \\
\hline Isopoda & Isopod $\mathrm{sp} 1$ & $5(1)$ & -8.36 & 5.44 & SG \\
\hline Isopoda & Isopod sp 2 & $15(3)$ & -10.44 & 5.90 & MM \\
\hline Planktotroph Ctenophora & Ctenophore spp & 17 & -18.31 & 7.24 & $\mathrm{SG}$ \\
\hline Porifera & Porifera sp 1 & 1 & -16.79 & 5.33 & SG \\
\hline Scyphozoa & Aurelia anrita & 1 & -16.45 & 7.93 & SG \\
\hline Scyphozoa & Phyllorhiza punctata & 3 & -12.92 & 1.48 & SG \\
\hline
\end{tabular}

Editorial responsibility: Ivan Nagelkerken, Nijmegen, Netherlands
Submitted: November 3, 2009; Accepted: January 21, 2011 Proofs received from author(s): April 2, 1011 